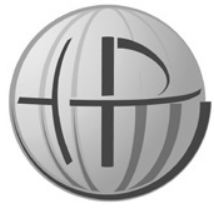

Horyzonty Polityki 2020, Vol. 11, No 35

\section{Piotr Mikusek}

http://orcid.org/0000-0002-9549-7616

Uniwersytet Warszawski

Wydział Filozofii i Socjologii

pmikusek1993@gmail.com

DOI: 10.35765/HP.1905

\title{
Rozwój międzynarodowego prawa konfliktów zbrojnych a sytuacja polityczna wojsk partyzanckich w Teorii partyzanta Carla Schmitta
}

\section{Streszczenie}

CEL NAUKOWY: Celem artykułu jest analiza sytuacji polityczno-prawnej nieregularnych sił partyzanckich i wpływu sfery politycznej oraz regulacji międzynarodowego prawa konfliktów zbrojnych na ewolucję partyzanta.

PROBLEM I METODY B AD AWCZE: Problem badawczy dotyczy trudności, jakie powstają przy próbie uregulowania prawnego funkcjonowania zjawiska występowania nieregularnych sił partyzanckich w trakcie konfliktów zbrojnych. Analiza oparta jest na dziele Teoria partyzanta Carla Schmitta i głównych regulacjach międzynarodowego prawa konfliktów zbrojnych normujących pozycję prawną partyzanta.

PROCES WYWODU: Punkt wyjścia stanowi próba zdefiniowania partyzanta i wskazania jego cech charakterystycznych w ujęciu Schmittańskiej Teorii partyzanta. Następnie wywód poprowadzony jest dwutorowo, w kontekście wpływu na funkcjonowanie partyzanta: zmian publicznego prawa międzynarodowego oraz przekształceń zachodzących w sferze politycznej. Czynniki te wpływają na ewolucję partyzanta przechodzącego z partyzanta tellurycznego do figury partyzanta.

WYNIKI ANALIZY NAUKOWEJ: Obecne regulacje międzynarodowe, tworzone w pierwszej połowie XX wieku, nie odzwierciedlają w należyty sposób skomplikowanej materii i doświadczeń związanych z wojskami partyzanckimi.

Sugerowane cytowanie: Mikusek, P. (2020). Rozwój międzynarodowego prawa konfliktów zbrojnych a sytuacja polityczna wojsk partyzanckich w Teorii partyzanta Carla Schmitta. Horyzonty Polityki, 11(35), 51-67. DOI: 10.35765/ HP.1905. 
WNIOSKI, INNOWACJE, REKOMENDACJE: Międzynarodowe regulacje dotykające zagadnienia partyzanta w celu zapewnienia jego należytej ochrony powinny limitować ramy ochrony, aby uniknąć zbyt szerokiego, a tym samym nieskutecznego, włączania partyzantów w system ochrony prawnej przewidzianej dla sił regularnych. Zmiany prawne dotykające zagadnienia partyzanta, ze względu na interdyscyplinarny charakter normowanej płaszczyzny, powinny być poprzedzone namysłem korzystającym z doświadczeń różnych dziedzin wiedzy.

\title{
SŁOWA KLUCzowe:
}

partyzant, prawo, polityka, regulacje, Carl Schmitt

\author{
Abstract \\ DEVELOPMENT OF INTERNATIONAL LAW \\ OF ARMED CONFLICTS AND POLITICAL SITUATION \\ OF PARTISAN FORCES IN CARL SCHMITT'S \\ "THEORY OF THE PARTISAN"
}

RESEARCH OBJECTIVE: The main goal of the article is to analyse the political and legal situation of irregular partisan forces as well as the impact of politics and the regulations of international law of armed conflict on the evolution of partisans.

THE RESEARCH PROBLEM AND METHODS: The research problem examines the difficulties that arise when intergovernmental organizations try to regulate the legal functioning of the phenomenon of irregular partisan forces during armed conflicts. The analysis is based on the Carl Schmitt's "Theory of the Partisan" and the main regulations of international law of armed conflicts regulating the legal position of the partisan.

THE PROCESS OF ARGUMENTATION: The starting point is an attempt to define the partisan and indicate its characteristics in terms of the Schmitt's Theory of Partisan. Then the argument is developed with twin-track approach, in the context of influencing the functioning of the partisan: changes in public international law and transformations taking place in the political sphere. These factors influence the evolution of the partisan from the telluric partisan to the figure of the partisan.

RESEARCH RESULTS: Current international regulations, created in the first half of the 20th century, do not properly reflect the complicated matter and experiences associated with partisan troops. 
CONCLUSIONS, INNOVATIONS AND RECOMMENDATIONS: International regulations on partisan issues, in order to ensure partisan's proper protection, should limit the protection framework in order to avoid too broad, and thus ineffective, inclusion of partisans in the system of legal protection provided for regular armed forces. Legal changes on the partisan issues, due to the interdisciplinary character of the said regulations, should be preceded by considerations taking into account the experience of various knowledge domains.

\section{KeYwORDS:}

partisan, law, politics, regulation, Carl Schmitt

\section{WSTĘP}

Celem niniejszego artykułu jest syntetyczne ujęcie oraz analiza hipotezy, w kontekście zaproponowanym przez niemieckiego filozofa i teoretyka prawa Carla Schmitta (Mouffe, 2011, s. 5-9), dotyczącej relacyjności pomiędzy przyjmowaniem aktów prawa międzynarodowego regulujących metody prowadzenia wojny (ius in bello) a sytuacją polityczną i prawną wojsk partyzanckich. Problematyka ta, w dorobku omawianego autora, najpełniej została omówiona w dziele Theorie des Partisanen: Zwischenbemerkung zum Bergiff des Politischen (Schmitt, 1963) ${ }^{1}$. W tym celu niezbędne będzie $\mathrm{w}$ toku pracy zdefiniowanie partyzanta oraz wskazanie, jakie zjawiska polityczne oraz akty międzynarodowego prawa publicznego, zdaniem Carla Schmitta, miały wpływ na jego ewolucję. Postaram się wykazać również, że autor Teorii partyzanta wyróżnia nie wprost dwie formy ewolucyjne partyzanta związane ze zmianą sfery polityczno-prawnej-partyzanta tellurycznego i figure partyzanta.

Na pozór może się wydawać, że przedmiotowa materia straciła na aktualności wraz z końcem XX wieku, kiedy to czas masowych i relatywnie licznych zgrupowań partyzanckich przeminął. Obecnie, w zakresie wielkości, osiągnięcie przez jakikolwiek ruch partyzancki powszechności na miarę Armii Krajowej czy też Narodowej Armii

1 Theorie des Partisanen została przetłumaczona na język polski - Teoria partyzanta: Uwagi na marginesie "Pojęcia polityczności", tłum. B. Cymbrowski, Wydawnictwo Krytyki Politycznej, Warszawa 2016. W dalszej części tekstu wszystkie odwołania będą odnosić się do tego wydania. 
Wyzwolenia Jugosławii byłoby niezwykle trudne. Wynika to nie tylko z rozwoju teoretycznego taktyk antypartyzanckich, lecz także z dostępności nowoczesnych technologii utrudniających ukrywanie swojej działalności i prowadzenie walki przez większe zgrupowania zbrojne. Nie oznacza to jednak, że Teoria partyzanta ma wyłącznie wartość historyczną dla filozofii politycznej i filozofii prawa. Zbadanie hipotetycznej relacji pomiędzy ewolucją partyzanta a rozwojem międzynarodowego prawa konfliktów zbrojnych oraz przekształceniami sfery politycznej może w istotny sposób przyczynić się współcześnie do lepszego zrozumienia wagi namysłu poprzedzającego zawieranie umów międzynarodowych, regulujących działania zbrojne. Dodatkowo, jak pokazuje empiria, w XXI wieku, nadal będziemy spotykać się z przykładami nieregularnych form prowadzenia wojny, np. poprzez wojny hybrydowe, których intensywność oraz częstotliwość najprawdopodobniej będzie zyskiwać coraz większe znaczenie w przyszłości (Bachmann i Gunneriusson, 2015, s. 77-78).

\section{FIGURA PARTYZANTA}

Partyzant jest to w rozumieniu słownika języka polskiego: „uczestnik walki zbrojnej na tyłach nieprzyjaciela, działający w oddziałach ochotniczych" (Szymczak, 1988, s. 610). Problem może sprawić określenie konkretnego momentu w dziejach, od którego można mówić o wystąpieniu partyzanta. Przyjmując szerokie kryteria odnoszące się wyłącznie do sposobu prowadzenia wojny i skupiając się na nieregularności technik walki, teoretyczne podwaliny można znaleźć już w Sztuce wojny Sun Zi (Smith, 2019, s. 3-4). Carl Schmitt stwierdza jednakże, że partyzant (telluryczny, ale jeszcze nie figura partyzanta), w nowoczesnym tego słowa znaczeniu, pojawia się dopiero od chwili rozpoczęcia w 1808 roku hiszpańskiej guerrilli prowadzonej przeciwko siłom Josepha I Bonaparte i okupacyjnym wojskom napoleońskim (Schmitt, 2016, s. 23-25). Warto zwrócić uwagę, że zgodnie z definicją zaprezentowaną na początku akapitu, o takim sposobie prowadzenia walki można mówić także przed XIX wiekiem. Podobne metody stosowali np. w starożytności Galowie i Germanie wojujący z siłami Rzymu (Wickham-Crowley, 2014, [b.n.s.]) czy żołnierze walczący w średniowieczu pod dowództwem Giergija Kastroti Skënderbeu 
przeciwko Imperium Osmańskiemu (Sedlar, 1994, s. 393). Schmitt zdecydował się jednak na użycie innego kryterium i przesunięcie punktu ciężkości przy definiowaniu partyzanta z samych metod walki na relację pomiędzy stronami konfliktu stwierdzając: „Jeśli chodzi o całościową teorię partyzanta, to trzeba pamiętać, że charakter i znaczenie jego nieregularności określane są charakterem i znaczeniem regularności, którą on kwestionuje" (Schmitt, 2016, s. 23-24). Ergo, o partyzancie powinno mówić się w kontekście nie samego sposobu prowadzenia działań zbrojnych i ich nieregularności, lecz w kontekście stosunku pomiędzy zorganizowaniem stron konfliktu. Użyte kryterium relacyjne w pełni wyostrza różnice pomiędzy nieregularnym a regularnym stylem prowadzenia walk podczas wojen napoleońskich. Powód wyjątkowości okresu napoleońskiego w tym względzie bierze się z rewolucji organizacyjnej armii i zmiany sposobu prowadzenia kampanii wojennych przez Napoleona Bonaparte. Odpowiadały za to przede wszystkim:

1. zorganizowanie systemu rekwizycji,

2. rozrost liczebności wojsk,

3. wprowadzenie powszechnego obowiązku służby wojskowej,

4. obrona krajowa, czyli wykorzystanie całego terenu państwa do prowadzenia działań zbrojnych.

Wszystkie te elementy sumują się, a ich wynikiem jest umasowienie i wzrost organizacji armii.

O spełnieniu kryterium relacyjnego w rozumieniu schmittańskim można mówić zatem od początków XIX w. Jednak partyzant w tym czasie stanowi w głównej mierze zjawisko o charakterze organizacyjno-wojskowym. Oczywiście jego proweniencja wiąże się ze zmianami zachodzącymi w sferze politycznej, co nie powinno zaskakiwać, biorąc pod uwagę całokształt poglądów filozoficznych Carla Schmitta, który uznaje sferę polityczną za immanentną część rzeczywistości (Skarzyński, 2012, s. 132-133). Na początku XIX wieku partyzant nie jest jeszcze zjawiskiem na wskroś politycznym i jego punkt ciężkości nadal osadzony jest bliżej cech militarno-organizacyjnych niż politycznych. Czynnikiem hamującym i niepozwalającym na upolitycznienie partyzanta w tym okresie, zdaniem Schmitta, jest klasyczna koncepcja wojny związana z ius publicum Europaeum (Schmitt, 2016, s. 29-32).

Ius publicum Europaeum jest pojęciem używanym przez Carla Schmitta na określenie swoistego porządku międzynarodowego 
między XVI a XX wiekiem, który odnosił się do funkcjonowania suwerennych państw europejskich, mających między innymi uprawnienia do prowadzenia wojen i obrony własnych interesów, jako równe sobie podmioty. Powstanie i rozwój tego ładu nie stanowił spójnego konceptu jednego autora, lecz konglomerat ewoluujących idei utworzonych na fundamentach różnych koncepcji należących do m.in. Baltasara de Ayala, Alberico Gentili czy Richarda Zoucha. Przy czym dla rozwoju ius publicum Europaeum dwie idee miały szczególne znaczenie - pierwsza to pojęcie formalnej wojny publicznej Hugo Grocjusza, druga natomiast to prawomocność i formalność prowadzenia wojny Emericha de Vattela (Schmitt, 2019, s. 121-151). Oba te ujęcia teoretyczne miały niejako zastąpić teorię wojny sprawiedliwej. Wius publicum Europeum przyjmuje się i aprobuje zasadę suwerenności państw, czego efektem jest zaakceptowanie również możliwości prowadzenia przez nie wojen (ius ad bellum). To zaś prowadzi do przeniesienia punktu ciężkości z niekwestionowanego ius ad bellum na sposób prowadzenia wojny, czyli ius in bello. Prowadzenie wojny zostaje zracjonalizowane, co w efekcie przyczynia się do humanizacji i jurydyzacji sposobów postępowania $w$ trakcie działań zbrojnych. Sposób, w jaki Schmitt opisuje ten model ładu, wskazuje, że pozostaje on dla niego pozytywnym układem odniesienia. Autor tymczasem obserwuje zachwianie tego porządku, które jego zdaniem przybiera na sile pod koniec XIX wieku, a do zupełnego upadku dochodzi wraz z zakończeniem I wojny światowej. O kresie ius publicum Europaeum przesądzają prawne rozstrzygnięcia zapadające podczas negocjacji traktatu wersalskiego i traktatów towarzyszących (Kervégan, 2011, s. 89).

Jak już zostało wskazane, cechą charakterystyczną wojny w ramach ius publicum Europaeum jest wzajemne uznanie własnej podmiotowości i pewnej równorzędności w prawie przez państwa toczące ze sobą wojnę. Jest to koncepcja, którą Carl von Clausewitz w traktacie O wojnie określa mianem wojny jako pojedynku, stwierdzając: „Wojna nie jest niczym innym, jak rozszerzonym pojedynkiem" (von Clausewitz, 1995, s. 3). Dopóki takie zasady funkcjonowały w prawie międzynarodowym partyzant, jako zjawisko, mógł występować wyłącznie na marginesie. Strony wojujące ze sobą nie kwestionowały swojej podmiotowości a stan wojny był narzędziem realizacji własnych polityk oraz sposobem na materializację partykularnych 
interesów. Sytuacja jednak zmienia się za sprawą dwóch czynników przekształceń sfery politycznej - których owocem jest, wcześniej już wspomniany, traktat wersalski i traktaty towarzyszące - odzierające z podmiotowości członków koalicji państw centralnych przez Ententę oraz ze względu na zmiany zachodzące $\mathrm{w}$ międzynarodowym prawie konfliktów zbrojnych, co zostanie opisane w następnym rozdziale artykułu. Powyższe zmiany doprowadzają do ewolucji partyzanta tellurycznego i pojawienia się figury partyzanta będącej par excellence figurą polityczną.

\section{REGULACJE MIĘDZYNARODOWEGO PRAWA KONFLIKTÓW ZBROJNYCH}

Międzynarodowe prawo konfliktów zbrojnych (zwane dalej: MPKZ) jest relatywnie młodą dziedziną prawa publicznego, która w pełni ukształtowała się wraz z końcem XIX wieku, a jej największy rozwój przypada na czterdziestolecie między 1895 a 1935 rokiem. Zalążki regulacji prawnych odnoszących się do konfliktów zbrojnych można oczywiście odnaleźć zdecydowanie wcześniej. W starożytności polis greckie opierały się w tym zakresie głównie na prawie zwyczajowym (Lanni, 2008, s. 469-489). Średniowiecze również dostarcza przykładów rozwoju tego typu regulacji - Zakon św. Jakuba od Miecza utworzony został w 1170 roku i miał na celu uwalnianie z rąk muzułmanów chrześcijan pojmanych $\mathrm{w}$ trakcie starć. Jest to zatem jedna z pierwszych instytucji powołana do ochrony ,jeńców". Inną regulacją która może być traktowana jako pomnik humanitarnego prawa konfliktów zbrojnych, jest kodeks Siete Partidas z 1260 roku króla Kastylii i Leonu Alfonsa X Mądrego z dynastii burgundzkiej. Przewidywał on regulacje odnoszące się do chrześcijańskich jeńców pojmanych $w$ trakcie walk przez innych chrześcijan (Niewiński, 2016, s. 25-58). Za przykład prób ograniczania użycia określonych technologii wojskowych może służyć natomiast kanon XXIX Soboru Laterańskiego II zakazujący, pod karą anatemy, używania kusz i łuków do starć pomiędzy chrześcijanami (Baron i Pietras, 2007, s. 143-165).

Wielka rewolucja francuska i nastanie epoki oświecenia tworzą fundamenty pod nowoczesne MPKZ. Za jedną z istotnych przyczyn powstania tych fundamentów należy uznać porewolucyjne 
przemiany polityczne oraz rozwój filozofii pozytywistycznej spod znaku między innymi Augusta Comte. Upodmiotawianie ludu i kierunkowanie poznania na rozumową weryfikację rzeczywistości powoduje filozoficzno-prawną próżnię w systemie ochrony stron konfliktów zbrojnych. Dotychczas to możni, uosabiający boski autorytet władzy, gwarantowali sobie wzajemnie podmiotowe traktowanie przeciwnika podczas wojen. Argument za takim rozumieniem może stanowić przykład wojny trzydziestoletniej, która charakteryzowała się szczególnym okrucieństwem. Przyczyny intensyfikacji terroru $\mathrm{w}$ tym starciu należy doszukiwać się $\mathrm{w}$ jego religijnym charakterze, gdzie strony wzajemnie nie uznawały w pełni podmiotowości wrogów, jako odszczepieńców, którzy przez wyłączenie się z chrześcijańskiej wspólnoty przestali być objęci mechanizmami ochronnymi. Dodatkowo wraz z umasowieniem armii w okresie wojen napoleońskich i totalnością zaistniałych walk nastała potrzeba uregulowania oraz nadania ram prawnych działaniom zbrojnym. Widać zatem kolejną przesłankę przesunięcia punktu ciężkości z ius ad bellum na ius in bello.

Tymi nowymi ramami prawnymi zostały regulacje tworzące MPKZ, w obrębie którego można wyróżnić trzy główne obszary unormowań: 1) konwencje haskie regulujące zasady, metody i sposób prowadzenia walk; 2) konwencje genewskie odnoszące się do ochrony osób i mienia mogącego ucierpieć podczas walk oraz 3) dodatkowe unormowania ograniczające stosowanie określonych narzędzi walki.

Dla wojsk partyzanckich szczególne znaczenie ma Regulamin stanowiący aneks do IV Konwencji haskiej dotyczącej praw i zwyczajów wojny lądowej z $1907 \mathrm{roku}^{2}$, tworzący trzystopniowy system ochrony sił partyzanckich.

Pierwszy stopień wynika z art. 1. IV Konwencji haskiej i rozciąga ochronę MPKZ także na „pospolite ruszenie” oraz „oddziały ochotnicze", jeżeli zostaną spełnione przez nie następujące warunki:

1. Mają na swoim czele osobę odpowiedzialną za swych podwładnych.

2. Noszą stałą i dającą się rozpoznać z daleka odznakę wyróżniającą. 
3. Jawnie noszą broń.

4. Przestrzegają w swych działaniach praw i zwyczajów wojennych.

Drugi stopień uregulowany został w art. 2. IV Konwencji haskiej i znajduje swoje zastosowanie, gdy wojska nieregularne nie zdołały się zorganizować przed nastaniem okupacji. W takim przypadku uzyskanie ochrony następuje po spełnieniu warunku jawnego noszenia broni oraz przestrzegania w swych działaniach praw i zwyczajów wojennych.

Trzeci stopień wynika z preambuły aktu, która stwierdza:

(...) w wypadkach, nieobjętych przepisami obowiązującymi, przyjętymi przez nie [strony konwencji], ludność i strony wojujące pozostają pod opieką i władzą zasad prawa narodów, wypływających ze zwyczajów, ustanowionych między cywilizowanymi narodami, oraz z zasad humanitarności i wymagań społecznego sumienia (...) w tym sensie należy zwłaszcza rozumieć artykuły 1 i 2 przyjętego regulaminu". Trzeci stopień oznacza zatem, iż partyzanci nie spełniający wymagań ochronnych z art. 1 i 2 są chronieni w ramach MPKZ, jednak na ogólnych zasadach prawa narodów oraz zwyczajów i jest to ochrona deklaratoryjna uzależniona de facto od dobrej woli okupanta. Co prawda nie przysługuje im pełnia praw, jednak strony konfliktu powinny $\mathrm{w}$ miarę możliwości proporcjonalnie rozciągać na nie uprawnienia wynikające z MPKZ i kierować się jego podstawowymi zasadami tj. zasadą: humanitaryzmu, rozróżniania, konieczności wojskowej i proporcjonalności (Marcinko, 2014, s. 61-91).

Dwa pierwsze stopnie ochrony wprowadzają wysokie wymogi stawiane samym partyzantom, aby mogli skorzystać $\mathrm{z}$ ochrony $\mathrm{w}$ ramach MPKZ. Trzeci stopień ma natomiast charakter deklaratoryjny.

III Konwencja genewska o traktowaniu jeńców wojennych z 1949 roku $^{3}$ wprowadziła istotne zmiany w sposobie rozumienia partyzanta. Doprecyzowano, iż pierwszy stopień ochrony w art. 1 IV Konwencji haskiej przysługuje zorganizowanemu ruchowi oporu, także działającemu poza granicami własnego terytorium (warto zwrócić uwagę na użycie słowa „terytorium” zamiast „kraju”/,państwa”). Dodatkowo kluczowym przekształceniom uległ drugi stopień ochrony. Chociaż treść wydaje się różnićjedynie nieznacznie, to doniosłość zmian jest istotna. Porównajmy zatem oba zapisy:

3 Zwana będzie dalej: III Konwencją genewską. 


\section{Art. 2. IV Konwencji haskiej:}

Ludność terytorjum niezajętego, która przy zbliżeniu się nieprzyjaciela dobrowolnie chwyta za broń, aby walczyć z wkraczającemi wojskami i nie miała czasu zorganizować się zgodnie $\mathrm{z}$ art. 1, będzie uważaną za stronę wojująca, jeżeli jawnie nosi broń i zachowuje prawa i zwyczaje wojenne.

Art. 4. lit. A pkt 6. III Konwencji genewskiej:

ludność terytorium nie okupowanego, która przy zbliżaniu się nieprzyjaciela chwyta spontanicznie za broń, aby stawić opór inwazji, a nie miała czasu zorganizować się $\mathrm{w}$ regularne siły zbrojne, jeżeli jawnie nosi broń i przestrzega praw i zwyczajów wojennych.

W zapisie tym można dostrzec kilka różnic. Pierwszą z nich jest zastąpienie pojęcia ",terytorium niezajęte" poprzez "terytorium nie okupowane", częściej spotykane w prawie międzynarodowym. Druga, to zmiana przesłanki dobrowolności chwycenia za broń na przesłankę spontaniczności. Trzecia dotyczy zmiany pojęcia „zachowuje prawa i zwyczaje wojenne" i zastosowanie "przestrzega praw i zwyczajów wojennych". Czwarta i ostatnia zmiana, będąca najważniejszą z punktu widzenia przedmiotowych rozważań, odnosi się do zakresu działania partyzantki: „chwyta za broń, aby walczyć z wkraczającymi wojskami” przekształcone zostaje na „,chwyta (...) za broń, aby stawić opór inwazji". Taki zapis znacząco rozszerza katalog zachowań, które mogą zalegalizować partyzanta i które zapewnią mu ochronę MPKZ.

$\mathrm{W}$ ramach art. 2. IV Konwencji haskiej partyzanci ujęci w walce przypominającej te prowadzone przez regularne siły zbrojne, po spełnieniu dodatkowych przesłanek, byli chronieni prawem międzynarodowym. Natomiast w ramach art. 4. lit. A pkt 6. III Konwencji genewskiej również inne formy oporu moga, choć nie wprost, kwalifikować się potencjalnie do ochrony w ramach MPKZ. Dotyczy to działań takich, jak przykładowo przeprowadzanie dywersji polegającej na wysadzaniu linii kolejowych. Warto również zwrócić uwagę, że w piśmiennictwie przyjmuje się, iż warunek ,jjawnego noszenia broni" nie wymaga, aby broń była noszona w sposób widoczny czy wręcz ostentacyjny, wystarczy, że druga strona konfliktu będzie miała świadomość, że ma do czynienia z wrogiem i może on posiadać broń (Mallison i Mallison, 1977, s. 56-58). 


\section{SCHMITTAŃSKA SYTUACJA POLITYCZNO-PRAWNA PARTYZANTA}

Dla Carla Schmitta w Teorii partyzanta cechami charakterystycznymi partyzanta są (Schmitt, 2016, s. 32-37):

- nieregularność,

- podwyższona mobilność,

- mundur oraz ujawniona broń,

- zaangażowanie polityczne,

- telluryczny charakter.

Na wstępie należy podkreślić, że wprowadzenie przez Schmitta przesłanki braku munduru oraz wymogu ujawniania broni nie oznacza jednak, jak już wcześniej zostało wyjaśnione, że taki partyzant nie podlega ochronie MPKZ. Potencjalnie możliwość taka nadal występuje. Aby móc zrozumieć przedstawianą przez Schmitta sytuację partyzanta $\mathrm{w} X \mathrm{X}$ wieku, konieczny jest ponowny powrót do omawianej klasycznej koncepcji wojny. Jak zostało wskazane wyżej klasyczna koncepcja wojny opierała się między innymi na suwerenności państw w rozpoczynaniu i kończeniu konfliktów zbrojnych, a także wzajemnym uznawaniu podmiotowości przez państwa. W klasycznej koncepcji wojny miejsce partyzanta jest wyłącznie marginalne. Nie pełni on roli samodzielnej i jego działania mają w głównej mierze charakter uzupełniający do działań regularnych sił. Takie rozumienie można spotkać u dziewiętnastowiecznych teoretyków wojny, jak Carl von Clausewitz, Georg Wilhelm von Valentini czy też Georg von Berenhorst (Jędrysiak, 2014, s. 34-54). Użycie sił partyzanckich przez stronę wojującą daje pewną przewagę, ale wiąże się również z większym ryzykiem, gdyż operujący w ramach "małej wojny", jak początkowo nazywano partyzantkę, mogą zostać potraktowani nie jak żołnierze, lecz jak zwykli kryminaliści.

Pierwszym czynnikiem zmieniającym podejście do partyzanta i powodującym erozję klasycznej koncepcji wojny są zmiany zapoczątkowane przez wielką rewolucję francuską i pojawianie się oraz rozwój w XIX w. masowych ruchów politycznych, jak np. komunizmu czy liberalizmu, które dokonują upolitycznienia wszystkich dziedzin życia (Kaczorowski, 1998, s. 45-46), w tym metod prowadzenia walki. Na potrzeby prowadzenia nowej i zintensyfikowanej walki 
politycznej należało znaleźć skuteczne narzędzia. Schmitt odwołując się do myśli marksistowskiej stwierdza:

Karol Marks i Fryderyk Engels zauważyli, że rewolucyjna wojna nie jest już wojną na barykadach w starym stylu (...). Lenin dostrzegł konieczność przemocy i krwawych rewolucyjnych wojen domowych i międzypaństwowych i dlatego zaakceptował konieczność wojny partyzanckiej jako niezbędny składnik całościowego zdarzenia rewolucyjnego (Schmitt, 2016, s. 63-64).

Za sprawą zmiany paradygmatu myślenia politycznego dochodzi zatem do utraty przez partyzanta cechy telluryczności. Telluryczny charakter oznacza, że partyzant, mimo swojej podwyższonej mobilności i nieregularności, jest powiązany z dającym się wskazać obszarem terytorialnym, $\mathrm{w}$ ramach którego działa defensywnie. Parantela partyzanta tellurycznego i ziemi nie ma charakteru wyłącznie geograficznego, lecz jest łącznością egzystencjalna, gdzie podmiot definiuje się przez pryzmat miejsca i przynależącej do niego kultury życia. Sytuacja zmienia się jednak, kiedy partyzant przestaje funkcjonować $\mathrm{w}$ odniesieniu i powiązaniu z jakąś przestrzenią terytorialną (materialną), a identyfikuje się z ideami abstrakcyjnymi, jak np. polityczne idee rewolucyjne o charakterze globalnym czy idee technokratyczne (Schmitt, 2016, s. 38). Wtedy też dochodzi do ewolucji partyzanta z partyzanta tellurycznego do figury partyzanta.

Przesłanka telluryczności ma kluczowe znaczenie dla koncepcji Carla Schmitta. Kryterium to w głównej mierze ma charakter filozoficzny i wpisuje się w całokształt namysłu nad państwem autora Teorii partyzanta. Sfera polityczności bowiem jest przestrzenią konfliktu koncentrującego się wokół linii podziału My - Oni, która to jest wyznaczana opierając się na stosunku przyjaźni i wrogości między grupami jednostek. Podziały te, we wspólnocie politycznej, doprowadzają do poczucia wrogości w stosunku do obozów wyznających inne wartości, tudzież modele życia, a tym samym rodzi dążenie do konfrontacji (Hirst, 2011, s. 14-15). Wraz z osłabianiem charakteru tellurycznego i wzmacnianiem zaangażowania politycznego następuje przejście od partyzanta tellurycznego do figury partyzanta. W Teorii partyzanta sam Carl Schmitt nie dokonuje wprost takiego rozróżnienia. Jednak wprowadzenie go wydaje się niezbędne dla lepszego zrozumienia problematyki prawnej podejścia do partyzantów. Figura 
partyzanta ma predyspozycje do internacjonalności, chociaż nie jest to warunek sine qua non. Istotniejsze jest polityczne zaangażowanie, w którym relacja figury partyzanta do sił regularnych nie opiera się na chęci obrony własnych ziem i pod ważenie praw agresora do nich, lecz ma charakter wrogości odmawiającej agresorowi podmiotowości politycznej, jako czynnikowi zagrażającemu treści jego własnej egzystencji, której to figura partyzanta broni. W efekcie czego dochodzi do brutalizacji narzędzi walki i samego konfliktu, w który uwikłana jest figura partyzanta. To właśnie na tej płaszczyźnie ujawniają się różnice między nią a partyzantem tellurycznym z początków XIX w.

Drugim czynnikiem wpływającym na ewolucję partyzanta i powodującym erozję klasycznej koncepcji wojny są zmiany zachodzące w sytuacji prawnej partyzanta. Zauważa to Carl Schmitt, porównując IV Konwencję haską z 1907 roku z III Konwencją genewską z 1949 i wskazując, że o ile regulacja haska starała się wyważyć interes okupantów i okupowanych, nadając partyzantom ochronę po spełnieniu rygorystycznych warunków, o tyle regulacja genewska w sposób znaczący rozszerza ochronę sił nieregularnych (Schmitt, 2016, s. 41-43). Nie można oczywiście zapomnieć, że III Konwencja genewska była odpowiedzią na wydarzenia II wojny światowej, kiedy to siły III Rzeszy, Cesarstwa Japonii oraz Włoch dopuściły się licznych zbrodni wojennych podczas walki przeciwko partyzantom, głównie na terenie Bałkanów oraz Europy Środkowej i Wschodniej. Takie podejście rozszerzające ochronę, mające charakter wybitnie humanitarny, wydaje się stać w zupełnej sprzeczności z praktyką wojenna, a co więcej, może wręcz prowadzić do osłabienia ochrony stron wojujących. Wynika to z faktu, że pozycję potencjalnego partyzanta mogą chcieć przyjąć również grupy, których celem nie jest opór przeciw okupantowi, lecz ukierunkowane są na prowadzenie nielegalnych działań, wykorzystując stan okupacji, jak np. grabieże lub zabory mienia. Zarówno partyzant, jak i bandyta poruszają się w sferze nielegalności, z tym że partyzant ma możliwość w pewnej mierze zalegalizowania swoich działań, podczas gdy bandyta znajduje się trwale poza porządkiem prawnym. Często jednak na wojnie precyzyjne oddzielenie od siebie różnych zachowań staje się niemożliwe nawet po stronie sił oporu, nie mówiąc już o siłach okupacyjnych. Warto w tym miejscu powrócić do figury partyzanta, która w odróżnieniu od partyzanta tellurycznego, któremu nie zależy 
na niszczeniu całego porządku i jego przejawów, może intencjonalnie dążyć do podejmowania działań nielegalnych i destabilizujących cały porządek okupacyjny. Jeżeli celem jest zniszczenie wroga, któremu odmawia się podmiotowości, wtedy każde działanie zmierzające ku temu jest tak samo usprawiedliwione. Nawet jeśli nie nastąpi to w przepisach prawa, to ostatecznie znajdzie "zalegalizowanie" na kartach historii. Figura partyzanta, przez swoją egzystencjalną wrogość dla okupanta (w szerokim tego słowa znaczeniu), będzie zazwyczaj operować poza prawem, a tym samym znajdować się poza ochronną MPKZ.

Do krytyki zachodzącego rozszerzania zakresu ochrony w ramach MPKZ można stosować argumenty filozoficzno-prawne wysuwane przeciwko nadmiernemu rozwojowi systemu ochrony praw człowieka. Ich autorami są między innymi tacy myśliciele, jak: Edmund Burke, Jeremy Bentham, Hannah Arendt, Calude Lefort, Marcel Gauchet, Jacques Rancièr, Étienne Balibar czy Slavoj Žižek wskazujący, że "abstrakcyjne i sformalizowane prawa ubezwłasnowolniają dla odmiany samą władzę, a w rezultacie odbierają jej moci i skuteczność" (Rakusa-Suszczewski, 2016, s. 11-33). W kontekście MPKZ i działań zbrojnych taka krytyka nie wynika bynajmniej z odrzucenia wartości ludzkiego życia lub z niechęci do humanitaryzowania działań zbrojnych. Chodzi bowiem o jasność i racjonalność pewnych rozgraniczeń. Rozszerzanie możliwości legalizacji nieregularnych metod oporu oraz włączanie ich do ochrony przypisanej oficjalnym, mundurowym siłom zbrojnym może doprowadzić de facto do rozmycia granicy, a tym samym dezintegracji całego systemu ochrony. Jak pokazuje historia wojen partyzanckich, ta dezintegracja nie spowoduje większej ostrożności po stronie walczących, lecz doprowadza do zawieszenia jakichkolwiek reguł. Co więcej figura partyzanta znajduje się w podwójnie korzystnej dla siebie sytuacji, ponieważ zaprzeczając prawomocności swojego wroga sam może wysuwać roszczenia do objęcia ochroną samej siebie. Zauważa to Carl Schmitt stwierdzając:

Cztery konwencje genewskie z 12 sierpnia 1949 r. są dziełem ludzkich uczuć i humanitarnego rozwoju zasługującego na podziw. (...) Lecz rozluźniając, czy wręcz kwestionując te istotne rozróżnienia [na wojsko i cywilów], konwencje otwierają drzwi takiemu rodzajowi wojny, który świadomie burzy te jasne podziały (Schmitt, 2016, s. 48). 


\section{ZAKOŃCZENIE}

Partyzant (zarówno ten telluryczny, jak i figura partyzanta) trwale uwikłany jest $\mathrm{w}$ konstelację politycznych przemian i wynikających z nich zmian w publicznym prawie międzynarodowym. Miejsce i materia działań nieregularnych sił zbrojnych są zagadnieniami trudnymi do jasnego określenia i wyznaczenia. Dzieje się tak ze względu na wyjątkowe miejsce partyzanta, który nie jest ani w pełni elementem dziedziny publicznej, ani też nie pozostaje wyłącznie podmiotem prywatnym. Wyzwania w zakresie ochrony przez MPKZ partyzantów pozostają wciąż aktualne. Co więcej, regulacje dotyczące normowania konfliktów już obecnie wystawiane są na próbę i muszą radzić sobie z nieoczywistymi i trudnymi do kwalifikacji sposobami prowadzenia działań zbrojnych, jak metody wykorzystywane przez terrorystów czy podczas wojen hybrydowych. Jest to przejaw wskazywanej w niniejszym artykule ewolucji tellurycznego partyzanta $\mathrm{w}$ stronę upolitycznionej figury partyzanta. Wyważenie wagi interesów w takich przypadkach jest o tyle trudne, że składa się ona z co najmniej kilku szal, m.in.: interesu cywilów mogących ucierpieć podczas walki, bezpieczeństwa narodowego państw narażonych na ataki, niezbywalnych praw uczestników walk oraz politycznego interesu stron konfliktów.

Wnioskiem de lege ferenda, jaki można wysnuć po zbadaniu niniejszej materii, jest postulat podjęcia próby wyważenia interesów poszczególnych stron i wzięcie pod uwagę nie tylko wartości prawnie chronionych, ale także argumentów natury politycznej. Nie wydaje się, aby możliwe było znalezienie rozwiązania zadowalającego, nawet nieznacznie, wszystkie strony. Tym niemniej warto, aby przy tworzeniu nowych regulacji wzięli udział nie tylko politycy i wojskowi, lecz także podmioty i osoby zajmujące się zagadnieniami polemologicznymi. Carl Schmitt w swoim dziele Teoria partyzanta zasygnalizował konteksty, w których warto rozwijać namysł nad normami kształtującymi sytuację prawną uczestników „małej wojny". Pomimo naturalnego odruchu humanitaryzmu i sprzyjania partyzantowi, tj. stronie potencjalnie słabszej, należy mieć na uwadze także interesy strony, wydawałoby się, silniejszej. W innym wypadku może okazać się, że państwa nie będą decydować się na prowadzenie otwartych starć oscylujących w pewnych ramach prawnych, 
lecz zaczną korzystać z metod nieoficjalnych i znajdujących się poza prawnymi unormowaniami, a tym samym dającymi pole do nadużyć. Dlatego, jak pisał Schmitt:

(...) niejedna ostrożnie stylizowana, oparta na kompromisie normalizacja sprawia wrażenie wąskiego mostu nad przepaścią, kryjącą w sobie brzemienną w skutki przemianę pojęć wojny, nieprzyjaciela i partyzanta (Schmitt, 2016, s. 48).

\section{BibLIOGRAFIA}

Bachmann, S.D. i Gunneriusson, H. (2015). Hybrid Wars: The 21st-Century's New Threats to Global Peace and Security. Scientia Militaria, South African Journal of Military Studies, 43 (1), 77-98.

Baron, A. i Pietras, H. (2007). Dokumenty Soborów Powszechnych: tekst grecki, łaciński, polski, tom 2. Tłum. A. Baron. Kraków: Wydawnictwo WAM - Księża Jezuici.

Bierzanka, R. (1949). Partyzanci ze stanowiska prawa międzynarodowego. Roczniki Prawa Międzynarodowego, 85-116.

Bierzanka, R. (1967). Status międzynarodowy partyzantów i członków ruchu oporu. Sprawy Międzynarodowe (5), 35-56.

Hirst, P. (2011). Decyzjonizm Carla Schmitta. W: C. Mouffe, Carl Schmitt. Wyzwanie polityczności, tłum. T. Leśniak (13-26). Warszawa: Wydawnictwo Krytyki Politycznej.

Jędrysiak, J. (2014).,,Mała wojna”w pruskiej myśli wojskowej 1815-1848. Scientific Journal of the Military University of Land Forces, 173(3), 34-54.

Kaczorowski, P. (1998). My i oni: państwo jako jedność polityczna: filozofia polityczna Carla Schmitta w okresie republiki weimarskiej. Warszawa: Szkoła Główna Handlowa.

Kervégan, J.-F. (2011). Carl Schmitt i jedność świata. W: C. Mouffe, Carl Schmitt - wyzwanie polityczności, tłum. P. Płucienniczak (69-96). Warszawa: Wydawnictwo Krytyki Politycznej.

Lanni, A. (2008). The Laws of War in Ancient Greece. Law and History Review, 26 (3), 469-489.

Majmurek, J. (2011). Słownik pojęć. W: C. Mouffe, Carl Schmitt. Wyzwanie polityczności (261-271). Warszawa: Wydawnictwo Krytyki Politycznej.

Mallison, W. i Mallison, S. (1977). The Juridical Status of Irregular Combatants under the International Humanitarian Law of Armed Conflict. Journal of International Law, 9(1).

Marcinko, M. (2014). Podstawowe zasady międzynarodowego prawa humanitarnego konflitków zbrojnych. W: Z. Falkowski i M. Marcinko, 
Międzynarodowe prawo humanitarne konfliktów zbrojnych (61-91). Warszawa: Wojskowe Centrum Edukacji Obywatelskiej.

Międzynarodowy Komitet Czerwonego Krzyża. (24 maja - 12 czerwca 1971). Rules Applicable in Guerrilla Warfare. Report prepared for the Conference on Government Experts on the Reaffirmation and Development of International Humanitarian Law Applicable in Armed Conflicts. Genewa.

Mouffe, C. (2011). Wyzwanie Schmitta. W: Ch. Mouffe (red.), Carl Schmitt. Wyzwanie polityczności. W: C. Mouffe, Carl Schmitt. Wyzwanie polityczności, tłum. T. Leśniak (5-9). Warszawa: Wydawnictwo Krytyki Politycznej.

Niewiński, A. (2016). Traktowanie jeńców w średniowieczu. Przykłady zachodnioeuropejskie. Roczniki Humanistyczne, 64(2), 25-58.

Rakusa-Suszczewski, M. (2016). Prawa człowieka-między krytyką i apologią europejskiego modelu politycznego. Studia Europejskie, 77(1), 11-33.

Schmitt, C. (1963). Theorie des Partisanen: Zwischenbemerkung zum Begriff des Politischen. Berlin: Duncker \& Humblot.

Schmitt, C. (2016). Teoria partyzanta: uwagi na marginesie "Pojęcia polityczności". Tłum. B. Cymbrowski. Warszawa: Wydawnictwo Krytyki Politycznej.

Schmitt, C. (2019). Nomos ziemi w prawie międzynarodowym ius publicum Europaeum. Tłum. K. Wudarska. Warszawa: Fundacja Augusta Hrabiego Cieszkowskiego.

Sedlar, W.J. (1994). East Central Europe in the Middle Ages, 1000-1500. Seattle, London: University of Washington Press.

Skarzyński, R. (2012). Od chaosu do tadu: Carl Schmitt i problem tego, co polityczne. Warszawa: Wydawnictwo von borowiecky.

Smith, S.D. (2019). An Archaeology of Asymmetric Warfare. W: S.D. Smith i C.R. Geier, Partisans, Guerillas, and Irregulars: Historical Archaeology of Asymmetric Warfare. Tuscaloosa: University Alabama Press.

Szymczak, M. (. (1988). Stownik jezyka polskiego, tom. 2 (L-P). Warszawa: Polskie Wydawnictwo Naukowe.

von Clausewitz, C. (1995). O wojnie. Tłum. A. Cichowicz. Lublin: Wydawnictwo "Test".

Wickham-Crowley, T.P. (2014). Guerrilla Warfare. W: J.A. Goldstone, The Encyclopedia of Political Revolutions. New York: Fitzroy Dearborn Publishers.

\section{Copyright and License}

This article is published under the terms of the Creative Commons Attribution - NoDerivs (CC BY- ND 4.0) License http://creativecommons.org/licenses/by-nd/4.0/ 